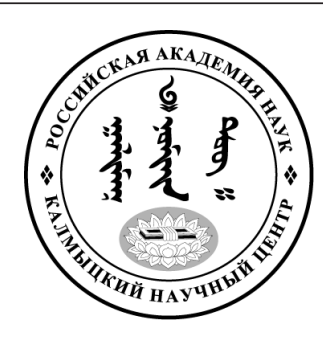

Published in the Russian Federation

Oriental Studies (Previous Name: Bulletin of the Kalmyk Institute for

Humanities of the Russian Academy of Sciences)

Has been issued as a journal since 2008

ISSN: 2619-0990; E-ISSN: 2619-1008

Is. 4 , pp. $615-626,2019$

DOI: 10.22162/2619-0990-2019-44-4-615-626

Journal homepage: https://kigiran.elpub.ru

УДК 930(517+470)

\title{
Барга (Хулунбуир) под контролем монгольских повстанцев в 1917 г.
}

Сергей Львович Кузьмин ${ }^{1}$

${ }^{1}$ Институт востоковедения РАН (д. 12, ул. Рождественка, 107031 Москва, Российская Федерация) доктор исторических наук, кандидат биологических наук, ведущий научный сотрудник ORCID: 0000-0001-9544-1359. E-mail: ipe51@yahoo.com

Аннотация. Целью работы является изучение малоизвестного периода в истории Барги (Хулунбуира) 1917 г., когда большая часть этого региона, включая его столицу, на короткое время перешла под контроль монгольских повстанцев. Материалы. С этой целью были изучены российские разведывательные и дипломатические документы из Архива внешней политики Российской империи (АВПРИ) и Российского историко-военного архива (РГВИА) с привлечением других источников. Результаты. На основе анализа исследованных материалов описывается характер управления Баргой в период, когда она находилась под контролем монгольских повстанцев в 1917 г., ее внутреннее положение, отношения повстанцев и нового руководства Барги с российскими официальными лицами на ст. Хайлар Китайско-восточной железной дороги (КВЖД), японскими военными, властями маньчжурских провинций, прилегавших к Барге, с властями Внешней Монголии, а также реакция партизан и властей Барги на кратковременную реставрацию цинской монархии. После захвата Хайлара монгольскими повстанцами российский МИД стремился как можно скорее восстановить спокойствие в Барге, предотвратить столкновения, которые могли бы угрожать безопасности КВЖД и автономии Барги, закрепленной российско-китайским соглашением 1915 г. В то же время МИД России разрешил временный ввод китайских войск в Баргу для удаления повстанцев, с последующим выводом китайских войск и сохранением автономии региона, хотя приоритетом было мирное урегулирование вопроса. Монгольские повстанцы были монархистами, которые выступали за восстановление власти маньчжурской династии. Правительство Барги, созданное под их влиянием, не имело реальной власти и занималось в основном поставками продовольствия для повстанцев и решением текущих вопросов. Хотя они поддерживали интенсивные контакты с японцами в Старом Хайларе, обвинять их в японофильстве неверно. Они поддерживали в основном хорошие отношения с русским населением Барги, но значительная часть баргутов и все дауры бежали в соседние регионы. Южная часть Барги, часть Внутренней Монголии и восток Внешней Монголии были опустошены повстанцами. Часть последних была готова войти в состав китайских провинциальных войск, но это было отложено.

Ключевые слова: Монголия, Барга, Хулунбуир, Китай, Маньчжурия, Япония, харачинский вопрос, Бавужав, независимость, автономия, международные отношения

Для цитирования: Кузьмин С. Л. Барга (Хулунбуир) под контролем монгольских повстанцев в 1917 г. Oriental Studies. 2019; (4): 615-626. DOI: 10.22162/2619-0990-2019-44-4-615-626. 


\title{
Barga (Hulunbuir) under the Control of Mongolian Guerrillas in 1917
}

\author{
Sergius L. Kuzmin ${ }^{1}$ \\ ${ }^{1}$ Institute of Oriental Sciences of the RAS (12, Rozdestvenka St., Moscow 107031, Russian Federation \\ Dr. Sc. (History), Ph. D. (Biology), Leading Research Associate \\ ORCID: 0000-0001-9544-1359. E-mail: ipe51@yahoo.com
}

\begin{abstract}
The work aims at the study of a little-known period in the history of Barga (Hulunbuir) in 1917 when a large part of this region, including its capital town, came under the control of Mongolian guerrillas for a short time. Materials. For this purpose, Russian intelligence and diplomatic documents from the Archive of Foreign Policy of the Russian Empire (Rus. AVPRI) and Russian State Archive of Military History (Rus. RGVIA), as compared to earlier published data, were studied. Results. The paper describes the character of governance practices in Barga during that period, internal situation, relations of the guerrillas and Barga's new authorities with Russian officials on the Hailar Railway Station, Japanese military, authorities of the Manchurian provinces bordering Barga and authorities of Outer Mongolia, as well as reaction of the guerrillas and Barga'sauthorities to the short-term restoration of the Qing monarchy. After Hailar was captured by the Mongolian guerrillas, the Russian Foreign Ministry sought to restore tranquility in Barga as soon as possible and prevent clashes that could threaten security of the Chinese Eastern Railway and the autonomy of Barga fixed by the 1915 Russian-Chinese Agreement. At the same time, the Russian Foreign Ministry allowed a temporary entry of Chinese troops into Barga to remove the guerrillas, with their subsequent withdrawal and preservation of the autonomy of the region, although the priority was a peaceful conciliation. Mongolian guerrillas were monarchists who stood for the restoration of the Manchu Dynasty'spower. The government of Barga, created under their influence, had no real authority and was engaged mainly in the supply of food for the guerrillas and solving current issues. Although they maintained intensive contacts with the Japanese in the Old Hailar, it is not correct to accuse them in Japonophilia. They maintained mostly good relations with the Russian population of Barga, but a significant part of the Barga people and all Daurs fled to neighboring regions. Southern part of Barga, a part of Inner Mongolia and eastern Outer Mongolia were devastated by the guerrillas. A part of the latter was ready to join Chinese provincial troops but it was delayed.
\end{abstract}

Keywords: Mongolia, Barga, Hulunbuir, China, Manchuria, Japan, Kharachin issue, Babujab, independence, autonomy, international relations

For citation: Kuzmin S. L. Barga (Hulunbuir) under the Control of Mongolian Guerrillas in 1917. Oriental Studies. 2019;(4): 615-626. DOI: 10.22162/2619-0990-2019-44-4-615-626.

\section{है}

\section{Введение}

В 1911 г. Монголия провозгласила свою независимость от империи Цин, что было вызвано цинской «новой политикой» китаизации Монголии, нарушавшей условия, на которых монголы в свое время подчинились маньчжурской династии Айсинь Гиоро. Приходившая в упадок Цинская империя, а затем Китайская республика не отказывались от «новой политики». Национально-освободительное движение монголов продолжалось, хотя после подписания Китайско-русско-монгольского Кяхтинского соглашения в 1915 г. руководство неза- висимой Монголии согласилось с признанием автономии Внешней Монголией под сюзеренитетом Китайской республики, тогда как Внутренняя Монголия была отделена от Внешней и рассматривалась как обычная часть Китая.

Часть отрядов повстанцев из Внутренней Монголии вернулась на родину и разоружилась, но отряд Бавужава, состоявший в значительной мере из монголов-харачинов, продолжил борьбу за независимость во Внутренней Монголии и в монгольском регионе Барга (Хулунбуир). После смерти Бавужава — весной 1917 г. — его отряд 
активно действовал в Барге, прилежащих районах Внутренней и Внешней Монголии. Действия этого отряда, известные как «харачинское движение», освещены в литературе фрагментарно. Хотя отряд Бавужава упоминается в некоторых обзорных публикациях [например, Скачков 1933: 120; История Монголии 2007: 43], лишь несколько исследований специально посвящено его деятельности [Лу 1979; Белов 1995; Лонжид, Өлзий 2002; Ностаева 2010; Кузьмин 2018; Кузьмин 2019; Nakami 1999; Nakami 2018; Ulaantana 2008].

Кульминацией «харачинского движения» стало занятие повстанцами столицы Барги — города Хайлара 11 мая 1917 г. ${ }^{1}$ и смена баргинского руководства. Затем в течение нескольких месяцев они контролировали значительную часть Барги. Это вызывало серьезную озабоченность не только Китая, претендовавшего на все территориальное «наследие» распавшейся империи Цин, но и Внешней Монголии, куда повстанцы совершали рейды из Барги, а также России, поскольку Хайлар был важной станцией на Китайско-восточной железной дороге (КВЖД). Этот эпизод истории Барги изучен слабо. Лишь в работе Е. В. Ностаевой [Ностаева 2010] об этом говорится подробнее, но детальная информация отсутствует.

Данная статья призвана, по возможности, заполнить этот пробел, преимущественно на основе сведений, содержащихся в Российском государственном военно-историческом архиве (далее - РГВИА) (прежде всего, донесений разведки Заамурского округа Пограничной стражи) и Архива внешней политики Российской империи (далее - АВПРИ), в первую очередь материалов переписки российских дипломатов, служивших в то время в Монголии, Маньчжурии и Китае.

\section{Основная часть}

Взятие Хайлара монгольскими повстанцами 11 мая 1917 г. описано мною в предыдущей статье [Кузьмин 2019]. Занятием Хайлара повстанцы не ограничились. 20 мая 1917 г. в Баргу прибыло еще 500 монголов-харачинов под командой Бумбужава. Они остановились в деревне в 5 верстах от Хайлара. Ожидалось прибытие еще 500 чел. Создавалась серьезная угро-

\footnotetext{
1 Здесь и ниже даты указаны по старому стилю.
}

за русскому поселку у КВЖД [Телеграмма вице-консула в Хайларе П. К. Усатого в Пекин от 20 мая 1917 г. АВПРИ. Ф. Миссия в Пекине. Оп. 761. Д. 396. Л. 31; Ф. Китайский стол. Оп. 491. Д. 3107. Л. 103]. В тот же день начальник российского гарнизона - командующий 1-м полком Заамурской железной дороги Рихтер сообщил П. К. Усатому: «Все меры, которые только можно принять, приняты. Гарнизон слишком мал, чтобы предпринять более решительные меры» [Послание Рихтера Усатому от 20 мая 1917 г. АВПРИ. Ф. Миссия в Пекине. Оп. 761. Д. 396. Л. 32]. На следующий день монгольские повстанцы подвезли к Хайлару орудия, которые сопровождали четыре японских артиллериста. По словам ухэрид ${ }^{2}$, харачины производили грабежи и насилия [Телеграмма Усатого в российскую миссию в Пекине от 21 мая 1917 г. АВПРИ. Ф. Китайский стол. Оп. 491. Д. 3107. Л. 104; Ф. [Вице-]Консульство в Хайларе. Оп. 573. Д. 2. Л. 93].

По требованию монгольских повстанцев власть в Барге сменилась (подробнее см.: [Кузьмин 2019]), хотя сами они не стали входить во временную администрацию. Собравшиеся в Хайларе высшие баргинские власти 22 мая 1917 г. посетили П. К. Усатого и заявили, что съезд для выборов нового правителя Барги состоится на следующий день. «Решили избрать фудутуном ${ }^{3}$ бывшего помощника фудутуна Чэхэджу. Ввиду того, что признание маньчжурской династии по требованию харачинов повлечет репрессии со стороны китайского правительства, а признание Китайской республики вызовет полный разгром Хулунбуира, съезд решил объявить Хулунбуир независимым от Китая, не признавая в то же время маньчжурской династии. Съезд надеется, таким образом, мирно сговориться с харачинами, дав им в случае надобности некоторый выкуп. На 24 мая назначены переговоры высших властей Барги с харачинами. Баргинцы просят меня принять участие в этих переговорах» [Телеграмма П. К. Усатого в Пекин от 22 мая 1917 г. АВПРИ. Ф. [Вице-]Консульство в Хайларе. Оп. 573. Д. 2. Л. 94].

2 Ухэрида (угурда) - правитель, имевший права дзасака, т. е. удельного князя.

3 Фудутун - наместник, пользовавшийся правами губернатора. 
Съезд состоялся 23 мая 1917 г. Под давлением харачинов вместо бывшего фудутуна - даура Шэнфу новым фудутуном Барги был избран монгол-баргут Чэхэджа (Ань), его помощником - ухэрида монголов-олётов Бангунжав. Все чиновники из дауров были смещены и заменены баргутами (подробнее о конфликте повстанцев с чиновниками-даурами см.: [Кузьмин 2019]). Новые власти заявили П. К. Усатому, что «съезд объявил Хулунбуир независимым и вступает в мирные переговоры с харачинами, которые будто бы изъявляют согласие оставить Баргу. Власти надеются мирно уладить дело с харачинами и просят не допускать китайских войск, так как в таком случае Хулунбуир подвергнется разгрому с двух сторон» [Телеграмма П. К. Усатого из Хайлара в миссию в Пекине, 4-й отдел МИД, Управление КВЖД в Харбине от 24 мая 1917 г. и телеграмма Н. А. Кудашева П. К. Усатому от 24 мая 1917 г. АВПРИ. Ф. Миссия в Пекине. Оп. 761. Д. 396. Л. 38; Ф. [Вице-]Консульство в Хайларе. Оп. 573. Д. 2. Л. 19].

Российский посланник в Пекине князь Н. А. Кудашев ответил сообщившему об этом П. К. Усатому: «Так как объявленная независимость Барги есть нарушение соглашений с Китаем, то, по моему мнению, Вам следует воздержаться от участия в переговорах» [Телеграмма П. К. Усатого из Хайлара в миссию в Пекине, 4-й отдел МИД, Управление КВЖД в Харбине от 24 мая 1917 г. и телеграмма Н. А. Кудашева П. К. Усатому от 24 мая 1917 г. АВПРИ. Ф. Миссия в Пекине. Оп. 761. Д. 396. Л. 38; Ф. [Вице-]Консульство в Хайларе. Оп. 573. Д. 2. Л. 19].

В вину Шэнфу новая баргинская власть ставила то, что он вел одновременно переговоры с Цицикаром (т. е. с китайской провинциальной администрацией в г. Цицикар) и с Шаньци - носителем одного из высших маньчжурских титулов «князь Су», одним из лидеров монархического движения. Шэнфу на это возражал, что самостоятельную политику он не вел, а все предварительно обсуждал на совете со своим помощником Аном (Чэхэджой) и ухэридами. Шэнфу согласился передать новому фудутуну хранившиеся у него 70000 руб. и печать, полученную им в 1912 г. от монгольского Богдо-хана из Урги 4 , но не передал печать, присланную

${ }^{4}$ Как символ присоединения Барги к Монголии. из Пекина ${ }^{5}$. Чэхэджа требовал также и ее [Разведка Заамурского округа Пограничной стражи, Харбин, 17 июня 1917 г. РГВИА. Ф. 1558. Оп. 4. Д. 33. Л. 314-314об.].

Новый правитель Хулунбуира и его помощник направили П. К. Усатому 26 мая 1917 г. следующее послание: «Консулу великого Российского государства в Хайларе. Принимая во внимание, что фудутун нашей земли Шэнфу потерял власть и дела и 3-го числа этого месяца оставил вместе с чиновниками город и присутственное место, захватив печать, казенные деньги, солонский, баргутский и олётский главные начальники и все чиновники, собравшись, по соглашению с сановниками монгольских солдат (харачин), приняли город и присутственное место. Но, признавая невозможность быть всегда подверженными превратностям и тревогам, имея в виду успокоение знамен, все условились, что пока устанавливается современное положение, временно установить единство (самостоятельность) и страну охранять самим, а нас, Чэхэчжа и Бангунчжаба, назначить правителем и помощником правителя. В силу необходимости, для успокоения мыслей, мы приняли это назначение и решили, совместно с главными начальниками и чиновниками, водворить в стране спокойствие в трудное время. Уведомив всех об этом, доводим до сведения почтенного консула и просим по-прежнему по дружбе оказывать покровительство. Присовокупляем, что на это сообщение временно приложена печать олётского главного начальника. Сего ради послано. Год Красной Змеи, 18-го числа 4-го месяца» [АВПРИ. Ф. Миссия в Пекине. Оп. 761. Д. 396. Л. 42 (русск. перев.); Ф. Миссия в Пекине. Оп. 761. Д. 396. Л. 43 (монг. ориг.); краткое сообщение об этом: Разведка Заамурского округа Пограничной стражи, Харбин, 10 июня 1917 г. РГВИА. Ф. 1558. Оп. 4. Д. 33. Л. 248-248об.].

Начальник 4-го политического отделения МИД Г. А. Козаков, недовольный развитием событий в Барге, телеграфировал П. К. Усатому 25 мая 1917 г., что обязанность принятия мер к улаживанию инцидента лежит, прежде всего, на нем, и указал: «Благоволите немедленно вступить в сношения с харачинами и потребовать от них прекратить монархическую агитацию и

${ }^{5}$ Как символ подчинения Китаю. 
удаления из пределов Барги. Укажите, что в противном случае мы не будем иметь оснований противиться вводу в Баргу китайских войск и подавления силою поднятого харачинами движения. Повидайте также находящихся между харачинами японцев и объясните им, что мы не будем их защищать от китайцев и требуем их удаления из лагеря харачинов. О последствиях телеграфируйте. Надеюсь, что Вы приложите больше рвения, чем до сих пор, к улаживанию этого дела» [АВПРИ. Ф. Миссия в Пекине. Оп. 761. Д. 396. Л. 45].

На результаты баргинского съезда Г. А. Козаков отреагировал так: «Мысль баргутских властей оградить себя как от китайцев, так и от харачин путем провозглашения независимости Барги - наивна. Благоволите объяснить баргутам, что мы не сочтем себя вправе защищать их от неизбежных попыток китайцев силой восстановить в Барге власть китайского правительства. Благоволите приложить все усилия, чтобы как баргутам, так и харачинцам стала ясна невозможность для них противостоять китайцам. Целью Вашей должно быть возможно скорее восстановить спокойствие в Барге, дабы не допустить столкновения, которое могло бы грозить безопасности Китайской Восточной ж. д. и свести на нет нашу работу по созданию автономии Барги» [Телеграмма Г. А. Козакова П. К. Усатому от 29 мая 1917 г. АВПРИ. Ф. Миссия в Пекине. Оп. 761. Д. 396. Л. 47].

Логично было ожидать вмешательства со стороны Китая в баргинские дела под предлогом наведения порядка. Однако часть повстанцев была готова перейти на службу в местные китайские войска. Появились сведения о решении $\mathrm{BPИО}^{6}$ командующего войсками и гражданского губернатора Хэйлунцзянской провинции генерала Сюй Ланьчжоу принять на службу 1 000-3 000 харачинов и разместить среди своих войск. Предполагалось, что согласятся на это около 1000 чел., но какого племени - неизвестно [АВПРИ. Ф. Миссия в Пекине. Оп. 761. Д. 397. Л. 9-9об.]. Однако генерал Сюй сообщил российскому консулу в Цицикаре С. В. Афанасьеву, что «соглашение с харачинами не состоялось благодаря тому, что таковые требовали, чтобы при их зачислении в китайские войска про-

\footnotetext{
${ }^{6}$ Так в документе. - C. K.
}

винции были бы зачислены и 10 японцев в качестве советников при них» [Телеграмма С. В. Афанасьева от 7 июня 1917 г. АВПРИ. Ф. Китайский стол. Оп. 491. Д. 3107. Л. 126]. Неуспех соглашения повышал вероятность ввода китайских войск в Баргу. В конце мая, до переговоров с китайцами, в Хайларе и окрестностях находились около 1000 монгольских повстанцев, о движении китайских войск было неизвестно [Телеграмма П. К. Усатого Н. А. Кудашеву от 30 мая 1917 г. АВПРИ. Ф. Миссия в Пекине. Оп. 761. Д. 396. Л. 46], хотя Управление КВЖД получило указания перевезти китайские войска, отправляемые в Баргу. МИД России передал губернатору Цицикарской провинции, что после восстановления спокойствия эти войска должны быть выведены согласно 4-й ст. соглашения по Барге от 24 октября 1915 г., в то время как порядок назначения фудутунов Хулунбуира предусмотрен 2-й статьей того же соглашения, которое остается в силе [Телеграмма Г. А. Козакова С. В. Афанасьеву от 31 мая 1917 г. АВПРИ. Ф. Китайский стол. Оп. 491. Д. 3107. Л. 117; Ф. Миссия в Пекине. Оп. 761. Д. 396. Л. 53].

Вероятно, в связи со сведениями о готовящемся движении китайских войск 10 июня около 300 харачинов отправились из окрестностей Хайлара на юг к озеру Цаган-нур примерно в 180 верстах от Хайлара - месту стоянки главных сил повстанцев [Телеграмма П. К. Усатого в 4-е политическое отделение МИД от 11 июня 1917 г. АВПРИ. Ф. Китайский стол. Оп. 491. Д. 3107. Л. 131].

Первый секретарь российской миссии в Пекине В. В. Граве прибыл в Цицикар и вступил в переговоры с Сюй Ланьчжоу. Была достигнута договоренность, что китайские войска будут посланы в Хайлар, лишь если Граве не удастся мирно уладить дело [Телеграмма В. В. Граве из Цицикара Н. А. Кудашеву от 12 июня 1917 г. АВПРИ. Ф. Китайский стол. Оп. 491. Д. 3107. Л. 132].

Таким образом, по просьбе В. В. Граве отправка четырех поездов войск против повстанцев была задержана до выяснения возможностей мирного решения. А через неделю выяснилось, что экспедиция и не могла состояться вследствие вспыхнувшего конфликта между Сюй Ланьчжоу и отказавшимся признавать его генералом Инь 
Шуном, из-за чего войска в Цицикаре и окрестностях должны были готовиться для экспедиции на восток против этого генерала [АВПРИ. Ф. [Вице-]Консульство в Хайларе. Оп. 573. Д. 7. Л. 67-119]. Мятежники вряд ли могли рассчитывать на успех, так как многие их части выразили покорность генералу Сюю, который твердо решил подавить мятеж [Телеграмма управляющего консульством в Цицикаре Симонолевича П. К. Усатому от 15 июня 1917 г. АВПРИ. Ф. Миссия в Пекине. Оп. 761. Д. 397. Л. 14]. 18 июня в Цицикаре состоялось совещание граждан и чиновников для изыскания средств к прекращению двоевластия, «гибельного для провинции» [Телеграмма Симонолевича П. К. Усатому от 18 июня 1917 г. АВПРИ. Ф. Миссия в Пекине. Оп. 761. Д. 397. Л. 20]. Данная ситуация была выгодна поддерживавшим харачинов японцам, так как сковывала китайские силы. Японцы поддержали волнения в Цицикаре. Оттуда на сторону Инь Шуна перебежал их сторонник полковник У Шицзе с двумя эскадронами [АВПРИ. Ф. Миссия в Пекине. Оп. 761. Д. 397. Л. 26].

Так как старые власти Барги перешли в полосу отчуждения КВЖД под охрану России, начальники монгольских повстанцев прислали в вице-консульство требование о выдаче Шэнфу и других чиновников, живших в русском поселке. Поскольку выдавать их не стали, харачины начали вести себя вызывающе по отношению к русским. Существовала опасность ареста Шэнфу и его чиновников в русском поселке харачинами [Телеграмма П. К. Усатого в миссию в Пекине от 8 июня 1917 г. АВПРИ. Ф. Китайский стол. Оп. 491. Д. 3107. Л. 127; Ф. [Вице-]Консульство в Хайларе. Оп. 573. Д. 2. Л. 23]. В связи с этим, по совету П. К. Усатого, Шэнфу и Фушан выехали из Хайлара и 12 июня прибыли в Цицикар [Телеграмма В. В. Граве из Цицикара в миссию в Пекине. АВПРИ. Ф. Китайский стол. Оп. 491. Д. 3107. Л. 132].

Ухудшению отношения монгольских повстанцев к России способствовала японская агитация, которая в начале июня приняла значительные размеры. Ее целью было ослабление российских позиций и усиление позиций повстанцев в Барге. «И лично, и через своих агентов - местных монголов-харачинов они [японцы] убеждают чиновни- ков и население в полном распаде России и в невозможности положиться на защиту и пользоваться ее покровительством. Они уверяют, что место России на востоке займет Япония, могущественное содействие которой баргинцы видели на примере харачинов». Новый правитель Барги по советам японцев у себя на место российского царя поставил портрет японского императора [Донесение П. К. Усатого в 4-е политическое отделение МИД и миссию в Пекине от 9 июня 1917 г. АВПРИ. Ф. Китайский стол. Оп. 491. Д. 3107. Л. 129]. Японский консул в Харбине уклонялся от свидания с П. К. Усатым, приехавшим в этот город [Разведка Заамурского округа Пограничной стражи, Харбин, 17 июня 1917 г. РГВИА. Ф. 1558. Оп. 4. Д. 33. Л. 314-314об.]. Однако корнем данной ситуации были не японские происки, а Февральская революция в России, свергнувшая монархию и запустившая распад государства.

Хотя японские дипломаты озвучили версию, что японцы в Барге - заложники у харачинов, не только жившие там русские и китайцы, но и японские офицеры, командовавшие харачинами, в разговорах с В. В. Граве отрицали это [АВПРИ. Ф. Миссия в Пекине. Оп. 761. Д. 397. Л. 11-12].

В сложившейся ситуации министр иностранных дел России потребовал отзыва японских офицеров из повстанческих отрядов, отметив, что японскому правительству уже неоднократно указывалось на нарушение им ст. 4 соглашения 1910 г. политической деятельностью японцев в сфере влияния России: «Ныне находящиеся с бандами харачинов в Барге японские офицеры, хорошо известные в Маньчжурии, руководят и, во всяком случае, участвуют в нападениях на Баргу, в требовании от баргутов присоединиться к монархическому движению, и дают таким образом китайцам вооруженной силой подавить движение и лишить баргутов автономии» [АВПРИ. Ф. Китайский стол. Оп. 491. Д. 3107. Л. 140].

На представление российского посла в Токио В. Н. Крупенского японское правительство ответило, что ничего не может сделать с участием японцев и предоставляет русским и китайцам расправиться с ними [Телеграмма В. В. Граве от 22 июня 1917 г., АВПРИ. Ф. Миссия в Пекине. Оп. 761. Д. 397. Л. 27]. Согласно отчету В. В. Гра- 
ве, министр иностранных дел и японский посланник в Пекине уверяли российских представителей в том, что японцы среди харачинов действуют на свой страх и риск, указаниями их снабжают квантунские военные власти [АВПРИ. Ф. [Вице-]Консульство в Хайларе. Оп. 573. Д. 7. Л. 67-119]. Это пример противоречий в подходах разных структур Японии к «харачинскому вопросу».

Прибывший в Хайлар В. В. Граве говорил монгольским повстанцам, что «они на службе не у Китая, почти совершенно нищего, а у японцев. Последние, ликвидируя монархическое движение, участвовавших в нем китайцев обратили в рабочих в своих предприятиях, харачинцев же заставили пойти на Баргу, чтобы быть здесь разбитыми китайцами. Выход - соглашение с последними при моем посредстве» [АВПРИ. Ф. Миссия в Пекине. Оп. 761. Д. 397. Л. 13об.].

В. В. Граве уговаривал повстанцев договориться с китайцами о переходе на их службу, но харачины не были откровенны с ним. «В их словах постоянно звучит нотка обиды на Россию на то, что на Кяхтинской конференции мы не позаботились о них и оставили их на произвол судьбы» [Телеграмма В. В. Граве в Миссию в Пекин, 10 июля 1917 г. АВПРИ. Ф. Миссия в Пекине. ОП. 761. Д. 397. Л. 59]. Имеется в виду то, что Китайско-русско-монгольское Кяхтинское соглашение 1915 г. зафиксировало автономию Внешней Монголии под сюзеренитетом Китая, но не распространялось на Внутреннюю Монголию, где национально-освободительное движение монголов было подавлено китайцами.

По сообщению В. В. Граве, влиятельные харачинские командиры Сэбджингэ и Бумбужав, ярые приверженцы японцев, были против перехода на китайскую службу, остальные - за, в основном потому, что не могли прокормить своих людей. Так, на службу в Мукденскую провинцию собирался перейти Чадарбал (Шадарбал), в Цицикар - Насанбаяр (Насун-Баир) [Телеграмма В. В. Граве в Пекин, Харбин и Петроград от 17 июня 1917 г. АВПРИ. Ф. Миссия в Пекине. Оп. 761. Д. 397. Л. 15]. Китайские власти также убедили перейти к ним на службу Доржа (Дорджи, Дорчжи, Дарчжий) [АВПРИ. Ф. [Вице-]Консульство в Хайларе. Оп. 573. Д. 7. Л. 67-119; разведсводка 17 июня 1917 г., АВПРИ. Ф. Миссия в Пекине. Оп. 761. Д. 397. Л. 71; телеграмма В. В. Граве из Хайлара в Пекин 26 июня 1917 г. АВПРИ. Ф. Миссия в Пекине. Оп. 761. Д. 397. Л. 32].

Ко времени приезда в Баргу Граве (то есть в июне 1917 г.) монгольские повстанцы там разделились на четыре отряда. Первый отряд (около 1500 чел.) стоял в южной части Барги на Цаган-нуре, при нем был главный начальник Чадарбал, 7 орудий и около 7 японцев. Второй отряд (около 1400 чел. под командой Доржа) - в деревне Наньтунь в 8 верстах южнее Хайлара, там не было ни японцев, ни орудий; Дорж считался японофобом. Третий отряд (около 500 чел.: 300 монголов и 200 хунхузов под командой Бумбужава) стоял в деревне Ситунь в 1,5 верстах от Хайлара, при нем было 2 бронзовых орудия образца до Русскояпонской войны, при орудиях были японцы. Четвертый отряд (100 чел. под командой Сэбджингэ) занимал Старый Хайлар, в нем находились главные начальники японских инструкторов Сэки и Садаки, у монголов известные как Гуан и Лин. Кроме того, по Барге бродили мелкие «шайки харачинов», грабивших местное население, главным образом, дауров [АВПРИ. Ф. [Вице-]Консульство в Хайларе. Оп. 573. Д. 7. Л. 67-119; Ностаева 2010: 46].

Монгольские повстанцы контролировали значительные территории Барги, Внутренней и Внешней Монголии. В руки японцев и повстанцев попали княжества Внутренней Монголии Дзун-Удзумчин и Барун-Удзумчин, аймак Хучит, халхаские княжества Эетей-бэйсэ, Чин-вана, Тун-дун-дзасака, южные хошуны Барги. Весь этот район был покинут местными жителями, ушедшими в Халху. Монастыри Асырин-сумэ, Арайн-сумэ, Тологай-сумэ, Дэдхошу-сумэ, Хозхошу-сумэ, Сумон-сумэ и другие, расположенные по р. Керулен, p. Аршан и близ оз. Буир-нур, лежали в руинах, ламы были прогнаны. Монастырь Халхин-сумэ уцелел, но ламы его покинули; по слухам, его охраняли русские рыбопромышленники, работавшие на оз. Буир-нур и p. Халх (Халхин-гол). С этой реки к урочищу Хурголчжи (очевидно, Хонгоджин) в Баргу перешли 500 монгольских повстанцев. Численность повстанческого отряда у Хайлара достигла 500 чел., его штаб находился в 
деревне Лопушка. Сообщалось, что командовал этим отрядом японец Сэки-нао ${ }^{7}$, при нем были помощник, 2 обер-офицера, 2 врача и 40 японских солдат, но по неофициальным сведениям их было до 100 (в основном, артиллеристы и пулеметчики - инструкторы повстанцев). Часть их прибыла по КВЖД в Хайлар, часть - через Монголию. При ставке японского командующего было два стальных скорострельных орудия, запас снарядов. Командующий занимал дом Шэнфу. Видя, что русские отвели войска в полосу отчуждения КВЖД, японцы перебросили к Хайлару свой отряд с орудиями и пулеметами. В Хайларе на всех домах были вывешены флаги с драконом (цинские) вместо прежних республиканских китайских. Харачины не трогали русских [Разведка Заамурского округа Пограничной стражи, Харбин, 17 июня 1917 г. РГВИА. Ф. 1558. Оп. 4. Д. 33. Л. 314-314об.].

По наблюдениям В. В. Граве, все харачины были монархисты и действовали на основе получаемых от князя Су указаний. По тем же наблюдениям, хотя в Старом Хайларе они поддерживали оживленные сношения с японцами, в японофильстве их обвинить было нельзя. Все японцы среди харачинов были запасные офицеры разных родов войск. Они подчинялись квантунским военным властям, присылавшим им приказания через Накаяму - японского агента в Цицикаре. В Барге их главным начальником был капитан Сэки, он находился в регулярных сношениях с Накаямой, в более важных случаях запрашивал инструкции из Порт-Артура через доверенных лиц из харачинов в сопровождении японцев. Например, 26 июня 1917 г. туда ездил Сэбджингэ. Инструкции харачинам писали от имени князя Су, при котором в Порт-Артуре состоял Н. Кавасима, бывший советник при князе в бытность того министром внутренних дел в последние годы маньчжурской династии. В одной из таких инструкций, посланной якобы князем Су новым баргинским властям, содержались поздравления по поводу их избрания, просьба двум избранным лицам исполнять обязанности главы Хулунбуира и его помощника, планы награждений. Проживая среди монгольских повстанцев, японцы обучили их военному строю, снабжали деньгами, оружием и провиантом,

\footnotetext{
${ }^{7}$ Сэбджингэ не упоминается.
}

руководили их действиями [АВПРИ. Ф. [Вице-]Консульство в Хайларе. Оп. 573. Д. 7. Л. 67-119].

После переворота в Барге монгольские повстанцы из Хайлара отправили депутацию к князю Су. Она вернулась из Дальнего, где встречалась с Су и Кавасимой 18 июня 1917 г. ${ }^{8}$ Депутация привезла печати новому правителю и командующему войсками Барги, а также предписания князя. Последний предложил харачинам оставаться в Барге и «ждать его указаний вступить в связь с усиливающимся в Китае монархическим движением». С депутацией вернулись японцы [Телеграмма В. В. Граве из Хайлара от 19 июня 1917 г. АВПРИ. Ф. Китайский стол. Оп. 491. Д. 3107. Л. 141; Ф. Миссия в Пекине. Оп. 761. Д. 397. Л. 24]. Такие итоги поездки означали формальное подчинение Барги восстановленному цинскому императору Пу И (девиз правления - Сюаньтун). Как отмечал В. В. Граве, при этих обстоятельствах трудно было рассчитывать на сговорчивость харачинов в переходе на китайскую службу.

Итак, 18 июня 1917 г. в Пекин вступили войска генерала Чжан Сюня, который восстановил на троне императора Пу И. Об этом Граве узнал, находясь в Хайларе: «Сейчас полковник Чжэнь сообщил мне о получении им телеграммы губернатора Сюя с известием о восстановлении маньчжурской династии и об утверждении его императором в должности. Таким образом, утверждение влияния японцев в Барге неминуемо, так как при их помощи монархия здесь провозглашена месяц тому назад харачинами. Единственный выход для нас из этого - отправление императором телеграммы главарям харачинов с приказом покинуть Баргу. При таких условиях считаю свое пребывание здесь излишним и жду указаний. Копии сообщаются в Пекин и Харбин [Телеграмма В. В. Граве из Хайлара от 22 июня ${ }^{10} 1917$ г. АВПРИ. Ф. [Вице-]Консульство в Хайларе. Оп. 573. Д. 1. Л. 46].

«Восстановленный монархический режим, по преобладающему здесь мнению,

${ }^{8}$ По старому стилю, или 1 июля по новому стилю, когда была реставрирована цинская монархия в Пекине.

${ }^{9}$ По старому стилю, или 1 июля по новому стилю.

105 июля по новому стилю. 
не может удержаться. Уже начались боевые столкновения близ станции Ланьфань железной дороги Пекин - Тяньцзин между сторонниками Чжан Сюня и Дуаня, в которых первые пострадали» [Телеграмма Н. А. Кудашева в вице-консульство в Хайларе от 23 июня $^{11} 1917$ г. АВПРИ. Ф. Китайский стол. Оп. 491. Д. 3107. Л. 142]. Но большинство монгольских повстанцев слепо верило реставрированному маньчжурскому императору [Телеграмма В. В. Граве из Хайлара в Пекин 26 июня ${ }^{12} 1917$ г. АВПРИ. Ф. Миссия в Пекине. Оп. 761. Д. 397. Л. 32]. Князь Су в послании правителям Барги сообщал о назначении им в помощь в Хайлар японских советников Сэки и Хаяси. Баргинские власти заявили, что японцы требуют соляную концессию на оз. Джурбэт и рыбные промыслы на оз. Далай-нор. П. К. Усатый ответил, что там есть русские кандидаты и японцам надо отказать [Телеграмма В. В. Граве из Хайлара в Пекин от 23 июня 1917 г. АВПРИ. Ф. Китайский стол. Оп. 491. Д. 3107. Л. 143; Ф. Миссия в Пекине. Оп. 761. Д. 397. Л. 30; Ф. [Вице-]Консульство в Хайларе. Оп. 573. Д. 1. Л. 7; Ностаева 2010: 46]. Сэки подтвердил российскому вице-консулу свое назначение советником при баргинских властях [АВПРИ. Ф. [Вице-]Консульство в Хайларе. Оп. 573. Д. 1. Л. 11-12].

В Маньчжурии возросла активность монархистов, возникали их новые отряды. Так, сообщалось, что в июле 1917 г. в харачинском хошуне Внутренней Монголии образовалась «шайка монгольских разбойников» свыше 4000 чел., среди которых было до 20 китайцев - членов монархической партии Цзуншэдан и шесть немцев «в качестве главных руководителей» [АВПРИ. Ф. Миссия в Пекине. Оп. 761. Д. 306. Л. 181].

В день реставрации цинской монархии 1 июля 1917 г. был опубликован указ императора Пу И, в котором говорилось о введении конституционно-монархического строя вместо республики, излагались основные положения нового правления, назначения на ключевые посты. Чжан Сюнь назначался канцлером с совмещением должностей генерал-губернатора Чжилийской провинции и главноуправляющего портами Северного Китая. Однако к предприятию Чжан Сюня положительно отнеслись лишь немногочис-

\footnotetext{
${ }^{11} 6$ июля по новому стилю.

129 июля по новому стилю.
}

ленные приверженцы Цинской династии. Вероятно, к восстановлению монархии отрицательно отнесся и Чжан Цзолинь, на которого мог рассчитывать Чжан Сюнь. Вооруженные столкновения генералов Дуань Цижуя и Чжан Сюня закончились поражением последнего [РГВИА. Ф. 1558. Оп. 4. Д. 29. Л. 20об.-22].

Восстановленная монархия продержалась всего 11 дней. После этого вновь смещенный Пу И издал декларацию, что план восстановления Цинской династии был задуман лично Чжан Сюнем без изъявления собственного желания Сюаньтуна; поэтому он не считает себя ответственным за кровопролитие [РГВИА. Ф. 1558. Оп. 4. Д. 29. Л. 22об.]. У китайцев в Барге возникла надежда, что неудача с восстановлением монархии сделает харачин более сговорчивыми, а при упрямстве Бумбужава будет применена сила [АВПРИ. Ф. Миссия в Пекине. Оп. 761. Д. 397. Л. 33].

Сэбджингэ и делегаты баргутов, при известии о восстановлении монархии выехавшие в Пекин через Дальний для выяснения обстановки, до Пекина так и не доехали. Сэбджингэ в Дальнем постоянно советовался с Кавасимой и привез в Хайлар приказание князя Су монгольским повстанцам оставаться в Барге, пока не выяснится положение в Китае, а для выигрыша времени вести с китайцами переговоры о переходе на их службу [Телеграммы В. В. Граве из Хайлара в Пекин от 26 июня и 10 июля 1917 г. АВПРИ. Ф. [Вице-]Консульство в Хайларе. Оп. 573. Д. 1. Л. 8, 61].

В начале июля монгольские повстанцы продолжали занимать Хайлар [АВПРИ. Ф. Китайский стол. Оп. 491. Д. 3107. Л. 151; Ф. Миссия в Пекине. Оп. 761. Д. 397. Л. 61]. В целом в Барге их силы были значительны: до 60-80 чел. - под командой Сэбджингэ; в деревне Ситунь - 500-600 чел. при 2 орудиях под командой Бумбужава, среди них более 200 китайских хунхузов, в основном прислуга при орудиях под охраной японцев; в деревне Наньтунь - до 1000 чел. под командой Доржа. Главные силы - до 1600 чел. при 2 орудиях под командой Чадарбала — находились в 150-160 верстах южнее Хайлара. 3 июля в Хайлар выехали с подарками и печатями для некоторых начальников харачинов из Цицикара полковник Чжэн (советник управления губернатоpa), Го Ятин (харачин, начальник Монголь- 
ского бюро в Цицикаре) и Фу Хай (харачин, его помощник) [Донесение разведки в российское консульство в Цицикаре. АВПРИ. Ф. Миссия в Пекине. Оп. 761. Д. 397. Л. 3638].

Это были шаги к включению повстанцев в китайские провинциальные войска. Вместе с тем эти войска проводили передислокацию, проводилась вербовка новобранцев [Донесение разведки от 6 июля 1917 г. АВПРИ. Ф. Миссия в Пекине. Оп. 761. Д. 397. Л. 47; Разведсводка от 13 июля 1917 г. Ф. Миссия в Пекине. Оп. 761. Д. 397. Л. 64], - очевидно, на случай новых стычек с повстанцами.

Для фуражировки харачины делали дальние рейды в Барге и восточной Халхе, не довольствуясь снабжением от властей Барги, которого явно не хватало. Очевидцы сообщали, что по трактам вдоль р. Керулен почти до самого оз. Буир-нур шли караваны беженцев из Барги. Монастыри Шутэн-сумэ, Асырин-сумэ (Асор-сумэ), Ороин-сумэ, Намюрин-хийд и другие в баргинском хошуне Цаган-ула были сожжены, равно как и многие кочевья, монастыри и храмы на берегах р. Аршан и у оз. Буир-нур. По дорогам встречались трупы монголов. Во Внешней Монголии харачины занимались грабежами к западу от Буир-нура (т. е. во Внешней Монголии), а также в княжествах Эрхэмсэг-бэйсэ и Хуру-дзасака, отчасти - Элдэн-вана. Главная волна беженцев из Барги шла вдоль берега Керулена, главным образом, в западно-халхаский хошун Сан-бэйсэ [Разведка Заамурского округа Пограничной стражи, Харбин, 3 июня 1917 г. РГВИА. Ф. 1558. Оп. 4. Д. 33. Л. 246]. В хошун Сан-бэйсэ перекочевали два западных хошуна Барги. Они просили не выгонять их, пока в Барге не восстановится порядок. Халхасцы согласились [Телеграмма российского генерального консула в Урге А. А. Орлова от 1 июля 1917 г. АВПРИ. Ф. Китайский стол. Оп. 491. Д. 3107. Л. 148].

Из примерно 22000 чел. восьми хошунов ново-баргутов из-за харачинских грабежей в Халху перекочевало пять хошунов около 8 000. Окончательно ушли в Цицикарскую провинцию все дауры - 702 чел. В Барге осталось около 4000 старо-баргутов, 2000 солонов и 400 олётов. Население было запугано харачинами и беспрекословно подчинялось им, солоны и олёты даже помога- ли им в грабежах. Баргутская милиция рассеялась частью среди баргутов, откочевавших в Халху, частью - на север от КВЖД, куда харачины опасались идти (вследствие близости КВЖД и российской границы). Выбранное новое правительство Барги фактически никакой власти не имело и было занято в основном доставкой продовольствия монгольским повстанцам и разборкой текущих дел [АВПРИ. Ф. [Вице-]Консульство в Хайларе. Оп. 573. Д. 7. Л. 67-119; Ностаева 2010: 46].

9 июля халхасцы получили из Хайлара известие о намерениях повстанцев двинуться в Цэцэнханский аймак Халхи, чтобы силой возвратить бежавших баргутов. Монголы решили отправить туда солдат, просили оружие и патроны у России [Телеграмма А. А. Орлова из Урги от 10 июля 1917 г. АВПРИ. Ф. Китайский стол. Оп. 491. Д.3107. Л. 154]. В связи с этим В. В. Граве предложил использовать казаков для охраны границы [Телеграмма В. В. Граве наказному атаману Забайкальского казачьего войска от 10 июля 1917 г. АВПРИ. Ф. Миссия в Пекине. Оп. 761. Д. 397. Л. 58-58об.]. По сообщению читинского областного комиссара от 9 июля 1917 г., 500 баргутов, спасаясь от харачинов, просили пропустить их в Забайкалье. Для выяснения была командирована особая комиссия [АВПРИ. Ф. Миссия в Пекине. Оп. 761. Д. 397. Л. 52, 56; Ф. Китайский стол. Оп. 491. Д. 3107. Л. 153; Ф. [Вице-]Консульство в Хайларе. Оп. 573. Д. 1. Л. 59].

Вместе с тем с российскими гражданами монгольские повстанцы всеми силами старались избегать конфликтов. На этот счет они получили самые строгие инструкции. Им запрещено было переходить полосу отчуждения КВЖД. Случаи ослушания и даже грабежа скота у русских были, но по первому требованию вице-консульства скот возвращали владельцам, а виновных наказывали. Вместе с тем повстанцы видели «полное разногласие» между российским населением Барги и российским правительством: россияне в Хайларе не относились враждебно к харачинам, считали их дела внутренним делом их с баргутами, настолько не сочувствовали репрессиям против них, что если бы местному гарнизону приказали выгнать харачинов из Барги, он отказался бы это делать. Более того: отдельные русские 
помогали отдельным харачинским группам в розыске и грабеже скота у баргутов [АВПРИ. Ф. [Вице-]Консульство в Хайларе. Оп. 573. Д. 7. Л. 67-119]. Это создавало препятствия возможному использованию российских войск для выдворения повстанцев из Барги. Кроме того, в связи с уходом «батальона смерти» из Хайлара, российский гарнизон там сильно уменьшился. Поэтому, как отмечал В. В. Граве, «всякие агрессивные действия против харачинов, в том числе арест Сэбджингэ, невозможны, ибо угрожают безопасности русских подданных и поселка» [Телеграмма В. В. Граве из Хайлара в Пекин от 5 июля 1917 г. АВПРИ. Ф. [Вице-]Консульство в Хайларе. Оп. 573. Д. 1. Л. 58].

\section{Заключение}

После захвата Хайлара монгольскими повстанцами МИД России ставил целью скорейшее восстановление спокойствия в Барге и недопущение столкновения, которое могло грозить безопасности КВЖД и

\section{Источники}

АВПРИ — Архив внешней политики Российской империи.

РГВИА — Российский государственный военноисторический архив.

\section{Sources}

Arkhiv Vneshnei Politiki Rossiiskoi Imperii [Archive of Foreign Policy of the Russian Empire].

Rossijskij gosudarstvennyj voenno-istoricheskij arhiv [Russian State Archive of Military History].

\section{Литература}

Белов 1995 - Белов Е. А. Антикитайское восстание под руководством Бабучжаба во Внутренней Монголии в 1915-1916 гг. // Анналы. 1995. № 2. С. 62-76.

История Монголии 2007 - История Монголии. ХХ век / ред. Г. С. Яскина. М.: Ин-т востоковедения РАН, 2007. 448 с.

Кузьмин $2018-$ Кузьмин С. Л. Положение повстанцев Внутренней Монголии после смерти их лидера Бавужава в 1916 г. // Oriental Studies. 2018. № 6. C. 2-14.

Кузьмин $2019-$ Кузьмин С. Л. Взятие монгольскими повстанцами столицы Барги в 1917 г. // Oriental Studies. 2019. № 2. C. 174-182. автономному статусу Барги. При этом МИД допускал временное введение китайских войск для удаления повстанцев с их последующим выводом и сохранением автономного статуса региона, хотя приоритетом было мирное урегулирование. Монгольские повстанцы были монархистами, стояли за восстановление власти маньчжурской династии. Созданное под их влиянием правительство Барги реальной власти не имело и занималось в основном поставкой продовольствия повстанцам и разбором текущих дел. Хотя с японцами в Старом Хайларе они поддерживали оживленные контакты, в японофильстве их обвинить было нельзя. С российским населением Барги отношения у них были в основном хорошие, но значительная часть баргутов и все дауры бежали в соседние регионы. Часть южной Барги, Внутренней Монголии и востока Внешней Монголии были разорены повстанцами. Часть последних готова была перейти в китайские провинциальные войска, но это затягивалось.

Лонжид, Өлзий 2002 - Лонжид 3., Өлзий Ж. Шударга баатар Бавуужав (= Шударга-Батор Бавужав). Улаанбаатар: «Согоонуур» ХХК, 2002. 47 c.

Лу 1979 - Лу Минхуэй (ред.). Бабучжабу ши ляо сюань бянь [Избранные исторические материалы о Бабужаве]. [S. 1.] [без м. и.]: Чжунго Мэнгу ши суэ хуэй, 1979. 162 с. (на кит. яз.)

Ностаева 2010 - Ностаева Е. В. Харачинский вопрос в Барге (1917 г.) // Восточный архив. 2010. № 1(21]. C. 43-48.

Скачков 1933 - Скачков П. Е. Внутренняя Монголия (экономико-географический очерк). М.: изд. науч.-иссл. ассоциации по изучению нац. и колониальных проблем, 1933. $151 \mathrm{c}$.

Nakami 1999 - Nakami T. Babujab and his uprising: re-examining the Inner Mongol struggle for independence // Memoirs of the Research Department of the Toyo Bunko. 1999. No. 57. Pp. 136-153.

Nakami 2018 - Nakami T. On Babujab and his troops: Inner Mongolia and the politics of imperial collapse, 1911-21 // Russia's Great War and Revolution in the Far East: Re-imaging the Northeast Asian Theater, 1914-22 (D. Wolff, Y. Shinji and W. Sunderland, eds.). Bloomington: Slavica Publishers, 2018. Pp. 351-358. 
Ulantana 2008 - Ulantana. [The response of eastern Inner Mongolians to the establishment of Bogd Khan Government: the case of Babujab] // Tōhoku Ajia kenkyū. 2008. No. 12. Pp. 97 118 (на япон. яз.).

\section{References}

[History of Mongolia: 20th Century]. G. S. Yaskina (ed.). Moscow: Inst. of Oriental Studies of RAS, 2007. 448 p. (In Russ.)

Belov E. A. The anti-Chinese rebellion led by Babujab in Inner Mongolia in 1915-1916. Annaly. 1995. No. 2. Pp. 62-76. (In Russ.)

Kuzmin S. L. Guerillas of Inner Mongolia after the death of their leader Babujab in 1916. Oriental Studies. 2018. No. 6. Pp. 2-14. (In Russ.)

Kuzmin S. L. The 1917 conquest of the capital town of Barga (Hulunbuir) by Mongolian guerrillas. Oriental Studies. 2019. No. 2. Pp. 174-182. (In Russ.)

Lonjid Z., Ulzii J. [The Honest Hero Babujab]. Ulaanbaatar: Sogonuur, 2002, 47 p. (In Mong.)

Lu Minghui (ed.). [Selected Historical Materials on Babujab]. (No data available): Zhongguo
Menggu shi xue hui, 1979. 162 p. (In Chin.)

Nakami T. Babujab and his uprising: re-examining the Inner Mongol struggle for independence. Memoirs of the Research Department of the Toyo Bunko. 1999. No. 57. Pp. 136-153. (In Eng.)

Nakami T.OnBabujab and his troops: InnerMongolia and the politics of imperial collapse, 1911-21. In: [Russia's Great War and Revolution in the Far East: Re-imaging the Northeast Asian Theater, 1914-22]. D. Wolff, Y. Shinji and W. Sunderland (eds.). Bloomington: Slavica Publishers, 2018. Pp. 351-358. (In Eng.)

Nostaeva E. V. The Kharachin issue in Barga in 1917. Oriental Archive. 2010. No. 1(21). Pp. 43-48. (In Russ.)

Skachkov P. E. [Inner Mongolia: an Essay on Economy and Geography]. Moscow: Association for Studies of Nationalities and Colonialism, 1933. 151 p. (In Russ.)

Ulantana. The response of eastern Inner Mongolians to the establishment of Bogd Khan Government: the case of Babujab. Tōhoku Ajia kenkyū. 2008. No. 12. Pp. 97-118. (In Jap.) 